\title{
Animal genetic resources and traditional farming in Vietnam
}

\author{
D.T. Dong Xuan ${ }^{1}$, I. Szalay', V.V.Su ${ }^{2}$, H.V. Tieu ${ }^{2}$ N. Dang Vang ${ }^{2}$ \\ ${ }^{1}$ Institute for Small Animal Research, Godollo 2100, P.O. Box 417, Hungary \\ ${ }^{2}$ National Institute of Animal Husbandry (NIAH), Hanoi, Tu Liem, Vietnam
}

\section{Summary}

The main animal feed sources in Vietnam are rice bran, rice straw, sweet potato, sugar cane, garden by-product and natural grasses. The majority of the rural population are considered to be farmers, $75 \%$ of them practice animal husbandry of which $95 \%$ includes animal production with local breeds or crosses. Local breeds or crosses produce $80 \%$ of meat and $75 \%$ of eggs. Animal production accounts for $20-25 \%$ of the total agricultural production. Pork represents $70 \%$ of domestic meat consumption.

Low external inputs are associated with the use of natural resources. Such types of natural resources as local breeds of animal are highly respected and used in a sustainable way. Uriu cattle survived the mechanisation in rice production due to the fact that the rice fields of Nghe An are full of rocks. Dong Tao chicken keeping is increasing thanks to the gourmet tastes of exigent Vietnamese consumers. Bau Qui ducks were maintained by Vietnamese of Thai ethnic tradition who killed all animals different from their breeds coming from other parts of the Quy Chau mountains, while the I pig faced the risk of extinction due to the priority given to imported pig breeds for intensive production. The tenacious and strongly built Mong Cai pig is a feature of households in semi-intensive production.

\section{Resumen}

Los principales recursos alimentarios en Vietnam provienen de la cáscara de arroz, residuos secos o paja del arroz, patata dulce, azúcar de caña, subproductos de horticultura y pastos naturales. La mayoría de las poblaciones rurales se consideran ganaderas, de las cuales el $75 \%$ se dedica a la cría ganadera y de éstos el $95 \%$ a la producción animal con razas locales o cruces. Las razas locales o sus cruces producen un $80 \%$ de carne y $75 \%$ de huevos. La producción animal representa un 20-25\% de la producción agrícola total. El cerdo representa un $70 \%$ del consumo de carne.

Los aportes externos se asocian a la utilización de recursos naturales. Estos recursos naturales, tales como las razas locales de animales, están altamente respetados y utilizados de forma sostenible. La raza vacuna Uriu ha sobrevivido a la mecanización de la producción de arroz debido a que los campos de arroz de Nghe An presentan suelos altamente rocosos. La cría de los pollos Dong Tao se ha incrementado gracias al gusto exquisito de los consumidores vietnamitas que así lo requieren. La cría de patos de raza Bau Qui está en manos de los vietnamitas de origen tailandés que tradicionalmente sacrifican todos aquellos animales que no pertenezcan a las razas provenientes de las montañas de Quy Chau. Mientras que los cerdos corren el riesgo de extinción debido a la prioridad que se da a las razas de cerdos importados de producción intensiva. La tenacidad y fortaleza de la raza porcina Mong Cai es uno de los rasgos que resaltan los ganaderos de esta producción semi-intensiva.

Keywords: Traditional farming, AnGR, Vietnamese agriculture, Feed resources, Pig breeds, Cattle, breeds, Poultry breeds, Conservation. 


\section{Introduction}

\section{Geographical and social background of Vietnamese agriculture}

Vietnam is a tropical country of lowlands, hills, mountains and forests. Its shape is an elongated ' $S$ ' form of 1650 kilometres in length while the narrowest part of Central Vietnam is only 50 kilometres wide. It has about 80 million inhabitants inhabiting a total surface area of 331688 square kilometres. Vietnam borders China $(1281 \mathrm{~km})$ to the north, Laos $(1555 \mathrm{~km})$ and Cambodia $(982 \mathrm{~km})$ to the west, and the Pacific Ocean $(3451 \mathrm{~km})$ to the east and the south. Vietnam has a remarkably diverse climate because of its wide range of latitudes and altitudes. Although the entire country lies in the tropics and subtropics, local conditions vary from frosty winters in the far northern hills to the year-round, equatorial warmth of the Mekong Delta. Because about one-third of Vietnam lies more than $500 \mathrm{~m}$ above sea level, much of the country enjoys a subtropical or, above $2000 \mathrm{~m}$, even a temperate climate. The summer monsoon brings hot air from the Gobi Desert, accompanied by heavy rainfall. Most of Vietnam receives about $2000-3000 \mathrm{~mm}$ of rain annually. The two deltas, the Red River (15 000 square kilometres) in the north and the Mekong (60000 sq km) in the tropical south, are the rice bowls providing for a fast-growing population. Vietnamese often describe their country as resembling a bamboo pole supporting a basket of rice on each end. The central region has large but diminishing forests, volcanic basalt soil, and profitable tea and coffee plantations (Le Ly, 1994).

Vietnam is dominated by the Viet ethnic group, which represents more than $88 \%$ of the total population. They coexist with more than 50 other ethnic groups, from Khmer to Chinese, from Thai to Hmong. A great number of these groups live in the central highlands or the northern border areas. (Le Ly, 1994). Most of the individual ethnic groups have a rural, agricultural lifestyle and are semi-nomadic, cultivating crops such as "dry" rice using slash-and-burn methods, which have taken a heavy toll on the environment. Because such practices destroy the ever dwindling forests, the government has been trying to encourage them to adopt more settled agricultural practices often at lower altitudes, with wet (paddy) rice and cash crops such as tea, coffee and cinnamon. Still, despite the allure of benefits like subsidised irrigation, better education and health care, a long history of nonconformist attitudes, coupled with a general distrust of the lowland ethnic-Vietnamese majority, keeps many away from the lowlands

\section{Main characteristics of agriculture in Vietnam}

Due to significant population pressures (only 0.1 ha arable land per capita) Vietnam has had to put a high priority on the development of sustainable agriculture (Dong Xuan and Szalay, 2003) (Figure 1). The traditional farming base of Vietnam is an integrated system of rice, root crops, fruit, vegetables, livestock and poultry (Viet Ly, 1998).

Vietnamese Government encourages peasants to follow the VAC integrated farming system. VAC, 'Vuon-Ao-Chuong', means Garden-Pond-Shed. VAC is a well-known name in Vietnam and is a farming system linking the garden (crops), pond (fish) and shed (animal) together. Farmers build their bamboo pigsty above the pond dug at the back of the garden. While the ducks swim and feed in the pond, fishes profit from the feed residue of all. Finally, sewage-water is conducted to the garden as manure. This integrated household farming system functions in a closed circle of alimentation and manure and results in increases in income to smallholders in the countryside without destroying the environment.

The agriculture of Vietnam is based mainly on rice production. Most of Vietnam's 


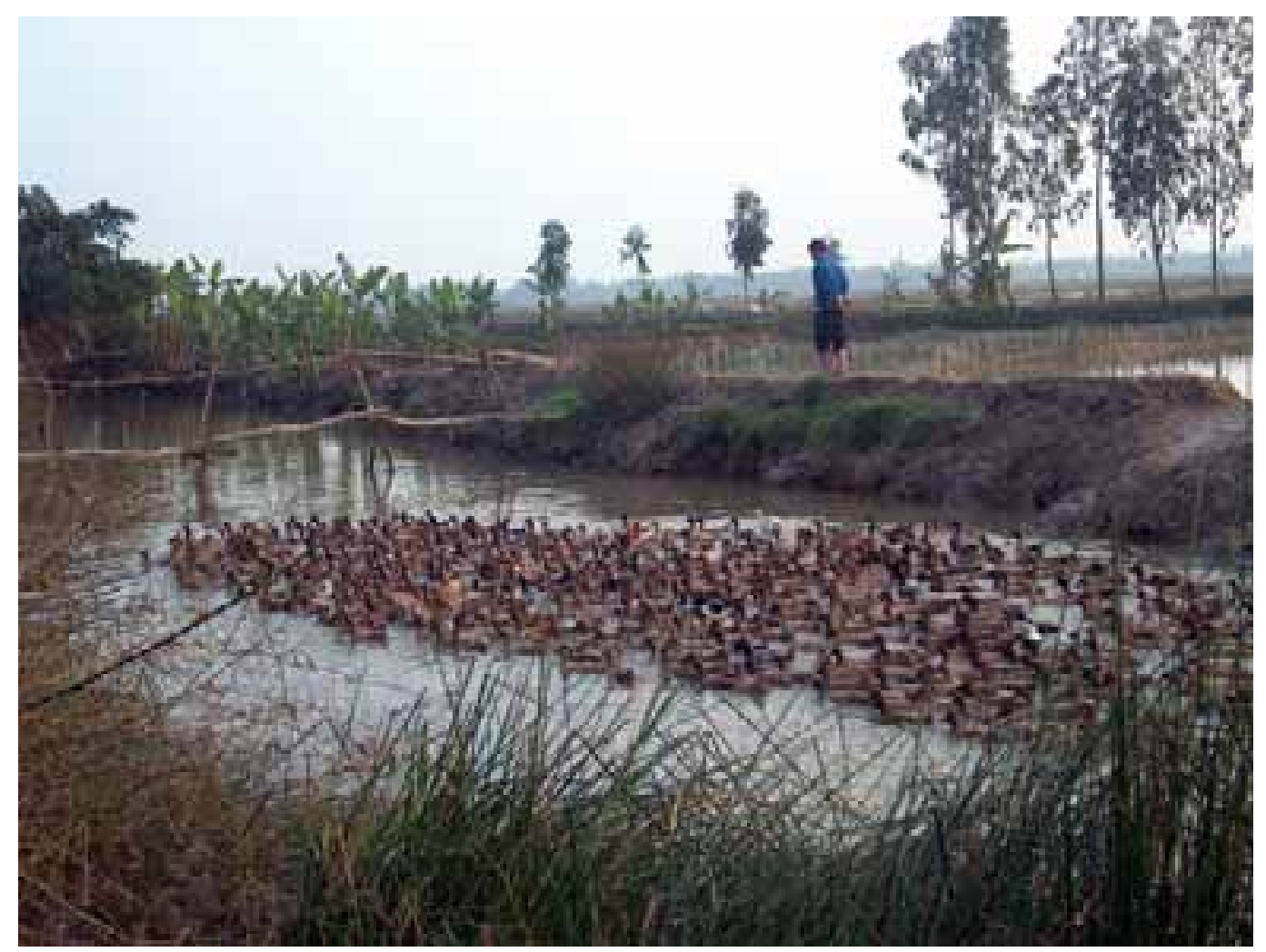

Figure 1. Traditional farming in Vietnam.

rice production is achieved without modern agricultural machinery, but economic reforms, combined with a strong work ethic have resulted in Vietnam moving from being an importer of rice during the 1980s to the world's third largest exporter of rice in the 1990s. On a more positive note, Vietnam has seen economic growth rates of around eight to nine percent annually in the past few years. Other crops such as maize, potato, sweet potato, manioc, groundnut, soybean, sugar cane, fruit trees and other perennial industry trees like coffee, rubber, tea and coconut are also important for Vietnamese agriculture.

According to the ecological and economic conditions of the country, Vietnamese agriculture can be separated into the following zones:

- The Northern Mountainous and Midland Region.

- The Red River Delta - The Northern Central Coastal Region.

- The Southern Central Coastal Region.
- The Central Highland Region - The Northestern of South Land.

- The Mekong River Delta Region.

The majority of the rural population are farmers, $75 \%$ of them practice animal husbandry. Animal production in Vietnam represents $20-25 \%$ of total agricultural production. Only $1 \%$ of meat is exported. Livestock enterprises are very small and comprise pigs, cattle, buffalo, chickens and ducks. There are different types of livestock found in each economic zone. In the northern mountainous and middle highlands the buffalo is most widely spread, while in Central Vietnam cattle production has an advantage ( $47 \%$ of the country's total herd). The chicken population is distributed evenly over the entire country, while duck flocks are concentrated mainly in the Mekong Delta region ( $58 \%$ of total duck flocks). The animal production sector is almost wholly in the hands of smallholders (Viet Ly, 1998) (Table 1.). 
Table 1. Distribution of pig population in the seven agro-ecological zones of Vietnam in 1995 (Viet Ly, 1998).

\begin{tabular}{lcc}
\hline Agro-ecological zones of Vietnam & \% of herd & \% of production \\
\hline 1. North mountains and midlands & 25.6 & 18.9 \\
2. Red river delta & 22.5 & 26.0 \\
3. North central coast & 16.4 & 13.0 \\
4. South central coast & 6.5 & 8.0 \\
5. Central highlands & 4.0 & 2.1 \\
6. North east of southland & 7.0 & 10.0 \\
7. Mekong river delta & 15.0 & 22.0 \\
$\quad$ Total & 100 & 100 \\
\hline
\end{tabular}

\section{Main animal feed resources in Vietnam}

Although it has been reported that a million hectares of so-called natural pasture exist, in reality Vietnam has very limited natural pasture. With an increasing population and the establishment of new economic zones, natural pastures have been reduced to small areas mixed with crops and building constructions. In the mountainous area, hilly land is either too steep to be grazed or the soil is too poor and dry. Management of pasture has been neglected and overgrazing has created serious damage causing soil erosion. The quality of grasses in natural pastures is poor. Re-growth of grasses is not strong enough and wild weeds easily

dominate it. Cultivated grasses have been studied and developed over many years in research institutes and on state farms.

Rice straw occupies a very important role in feeding ruminants. Normally, Vietnam has two rice cropping seasons per year and in some places there are three crops per year. There is about 20 million tons of rice straw produced per year. This amount is used as ruminant feed, fuel, litter and a part of it is burned in the field immediately after harvesting. An estimated $30 \%$ of rice straw is used to feed animals, which is approximately 6 million tons per year. Buffalo and cattle are fed with rice straw at night or on rainy and cold days when they cannot graze (Viet Ly, 1998).

Rice bran is also an important feed source. It can be used for pigs and for dairy cattle but is only used as a supplement for buffalo and cattle in periods of increased work.

Maize stems gathered after harvesting are also plentiful but are rarely used as animal feed rather they are utilised as fuel. Sweet potato vines are abundant and are used mostly for pigs rather than for buffalo or cattle. There are large amounts of peanut and soybean stems available, however their harvesting period is very short and storage is difficult, therefore, very little can be utilised as animal feed and most is used as a green manure.

Sugar cane is a special industrial crop in Vietnam due to its important by-products. Molasses is a high energy feed source (for beef cattle and buffalo and also for pigs). Sugar cane is harvested in the dry season. Sugarcane top and bagasse are important forage for ruminants in areas having prolonged dry periods. Sugar cane production in Vietnam is developing quickly and its by-products will become more important in ruminant feeding in the coming years.

Although the quality of agricultural by-products is low, their huge quantity makes them important for the development of animal husbandry in Vietnam (Viet Ly, 1998). 


\section{Animal genetic resources in Vietnam}

Traditionally in Vietnam, various kinds of indigenous animal genetic resources supplied a great deal of animal products to the Vietnamese people over thousands of years. The breeds were tenacious with few requirements, but in general exhibited quite low performance levels. Until 1970 many indigenous breeds were used within the extensive agricultural production system, but due to continuously changing demands, Vietnam was forced to import many kinds of high performance animal breeds and hybrids. Imported breeds were used for crossing with the Vietnamese indigenous breeds, but as of 1998 the low number of crossbred animals and animal breeds used for intensive production had had little impact when compared to local, indigenous animal breeds. For example, in 1996 there were 180 million poultry in Vietnam, of which $80 \%$ were indigenous Vietnamese breeds and $20 \%$ commercial breeds. These facts demonstrate the important role of indigenous animal breeds in Vietnam. In order to conserve indigenous animal breeds, the Vietnamese Government finances the programme 'Conservation of Animal Genetic Resources in Vietnam' (Thien, 1998). Some data, indicating the importance of local breeds are as follows:

- $80 \%$ of meat is produced by local breeds or crosses

- $75 \%$ of eggs are produced by local breeds

- $95 \%$ of farmers undertake animal production using local breeds or crosses Breeds intended for intensive production are kept mainly around big cities (Tieu et al., 2001). The various armed conflicts in which Vietnam has been involved over the past 50 years have had a highly negative influence on its economic and social development. In reality, slow economic development has resulted in the reduced exploitation of natural resources. A certain type of conservation of genetic resources was conducted until the 'Economic Reform' was introduced in 1990. Low external inputs were associated with the use of natural resources. This meant that such types of natural resources as local breeds of animals were highly respected and used in sustainable ways. This observation can be certified in the case of several local breeds.

Vietnam is a country with abundant livestock, among which 46 local breeds are known (Viet Ly, 1998). Positive characteristics of indigenous breeds are their high level of resistance to diseases, their efficient utilization of poor quality feed, tasty meat and good adaptability to various environments. Sixteen of the local breeds are widely used in mass production, population numbers of 25 breeds are decreasing, 2 breeds are in danger (Uriu cattle, White horse), 2 breeds are in extreme danger (Rough I pig, Ri chicken) and 3 breeds have been lost (Black I pig, Son Vi pig, Van Phu chicken) (Table 2.). Some typical Vietnamese indigenous breeds are mentioned below.

\section{Pig breeds}

\section{I pig (in extreme danger)}

After the armed conflicts in Vietnam, a typical parameter of increasing living standards was the availability of meat to consumers. Consequently, pig production took top priority in Vietnam for the following reasons:

- $70 \%$ of domestic meat consumption is pork.

- Two thirds of manure needed by traditional farming is supplied by pigs. In order to fulfil demands for meat, the country imported pig hybrids such as the Large White, Landrace, Duroc and Hampshire for intensive meat production. The evident increase in meat production contributed to the decrease of the I pig breed, the recent history of which paints a sad picture. Until the seventies the I pig was common and the most familiar breed to Vietnamese farmers in North Vietnam (Figures 2 and 3). Despite their slow growth rate, the I pig was one of the most important 
Table 2. List of Vietnam livestock breeds and their status (Tieu et al., 2001).

\begin{tabular}{|c|c|c|c|c|}
\hline Species & Breeds & Decreasing/Increasing & $\begin{array}{l}\text { In the } \\
\text { project }\end{array}$ & Mode for use \\
\hline \multirow[t]{4}{*}{ Cattle } & Yellow & Decreasing etc & & Purebred, crossed \\
\hline & U Riu & Endangered & $\mathrm{x}$ & Purebred, crossed \\
\hline & Hmong & Mass production & $x$ & Purebred, crossed \\
\hline & Phu Yen & Mass production & & Purebred \\
\hline \multirow[t]{2}{*}{ Buffalo } & Small & Mass production & & Purebred \\
\hline & Big & Mass production & & Purebred \\
\hline \multirow[t]{2}{*}{ Horse } & White & Endangered & $x$ & Purebred \\
\hline & Color & Increased & & Purebred \\
\hline \multirow[t]{10}{*}{ Pig } & Black I & Loss & $x$ & Purebred, crossed \\
\hline & Rough I & Extreme danger & & Purebred \\
\hline & Mong Cai & Mass production & $x$ & Purebred, crossed \\
\hline & Ba Xuyen & Decreasing & $x$ & Purebred, crossed \\
\hline & Thuoc Nhieu & Mass production & & Purebred, crossed \\
\hline & Nghe An Meo & Decreasing & $x$ & Purebred \\
\hline & Tay Nguyen Soc & Decreasing & $x$ & Purebred \\
\hline & Muong Khuong & Mass production & $x$ & Purebred, crossed \\
\hline & Quang Tri Mini & Decreasing & $x$ & Purebred \\
\hline & Son $\mathrm{Vi}$ & Loss & & \\
\hline \multirow[t]{14}{*}{ Chicken } & $\mathrm{Ri}$ & Decreasing & & Purebred, crossed \\
\hline & $\mathrm{Te}$ & $\begin{array}{l}\text { Extremely } \\
\text { Endangered }\end{array}$ & $\mathrm{x}$ & Purebred \\
\hline & Mia & Mass production & $x$ & Purebred, crossed \\
\hline & Ho & Decreasing & $x$ & Purebred \\
\hline & Dong Tao & Increased & $x$ & Purebred, crossed \\
\hline & Tau Vang & Mass production & $x$ & Purebred, crossed \\
\hline & Dwarf & Mass production & & Purebred \\
\hline & Oke & Decreasing & $x$ & Purebred \\
\hline & H'Mong Brown & Decreasing & $x$ & Purebred \\
\hline & H'Mong White & Decreasing & $x$ & Purebred \\
\hline & H'Mong Black & Decreasing & $x$ & Purebred \\
\hline & Van Phu & Loss & & Purebred \\
\hline & Tre & Decreasing & $x$ & Purebred \\
\hline & Choi (fighting) & Decreasing & & Purebred \\
\hline \multirow[t]{5}{*}{ Duck } & Bau Qui & Decreasing & $x$ & Purebred \\
\hline & Bau ben & Decreasing & $x$ & Purebred \\
\hline & $\mathrm{Co}$ & Decreasing & $x$ & Crossed \\
\hline & Ki Lua & Decreasing & $x$ & Purebred \\
\hline & Moc & Decreasing & $x$ & Purebred \\
\hline Muscovy duck & Trau & Decreasing & $x$ & Purebred \\
\hline \multirow[t]{3}{*}{ Goose } & De & Decreasing & $x$ & Purebred \\
\hline & Co & Decreasing & $x$ & Purebred \\
\hline & Lion & Decreasing & $x$ & Purebred \\
\hline \multirow[t]{2}{*}{ Rabbit } & Grey & Decreasing & $x$ & Crossed \\
\hline & Black & Decreasing & $x$ & Purebred, crossed \\
\hline \multirow[t]{2}{*}{ Goat } & Small & Decreasing & $x$ & Purebred, crossed \\
\hline & Bach Thao & Decreasing & $x$ & Purebred, crossed \\
\hline Sheep & Phan Rang & Decreasing & $x$ & Purebred \\
\hline Pigeon & Vietnam & Decreasing & $x$ & Purebred \\
\hline
\end{tabular}




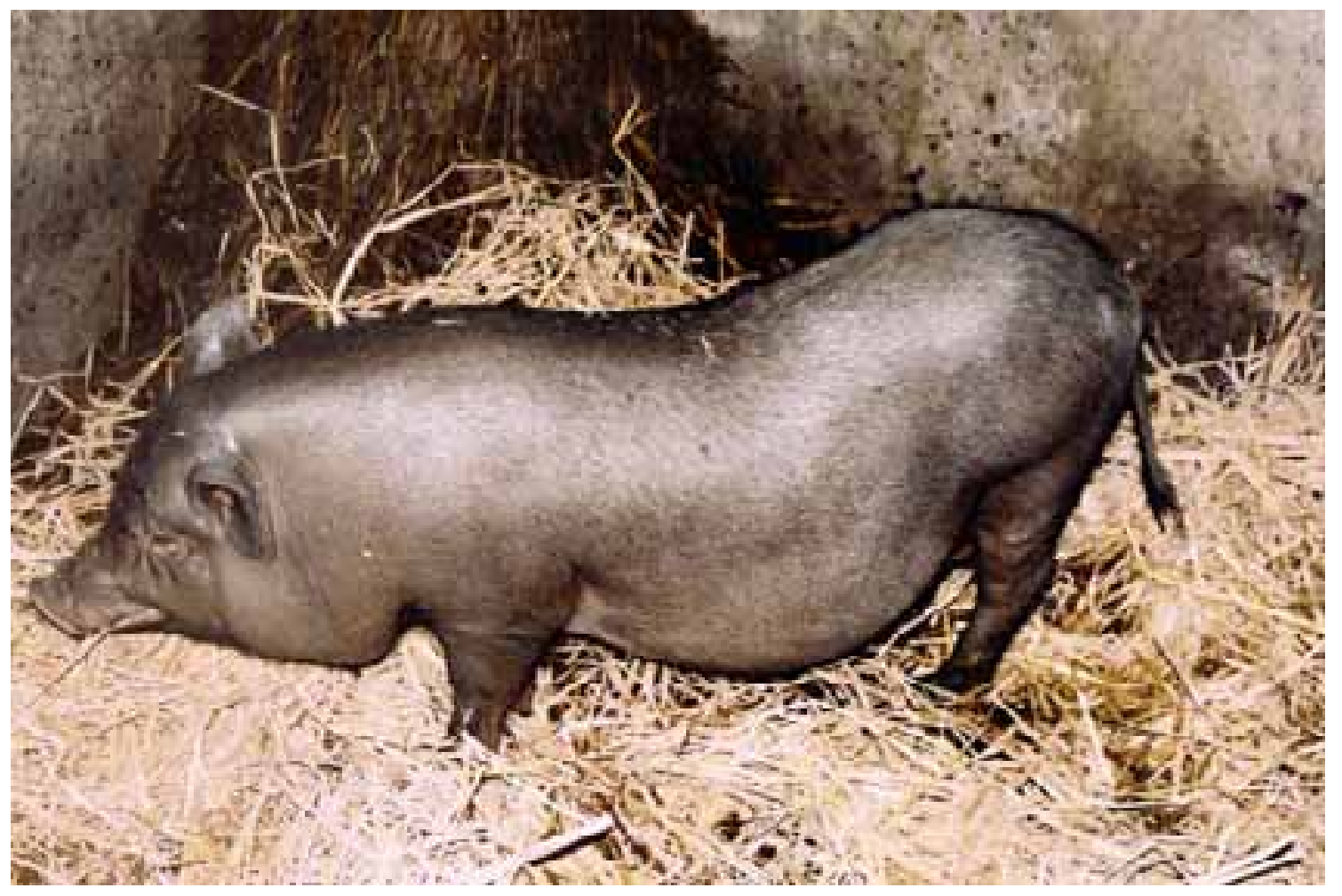

Figure 2. I pig female.

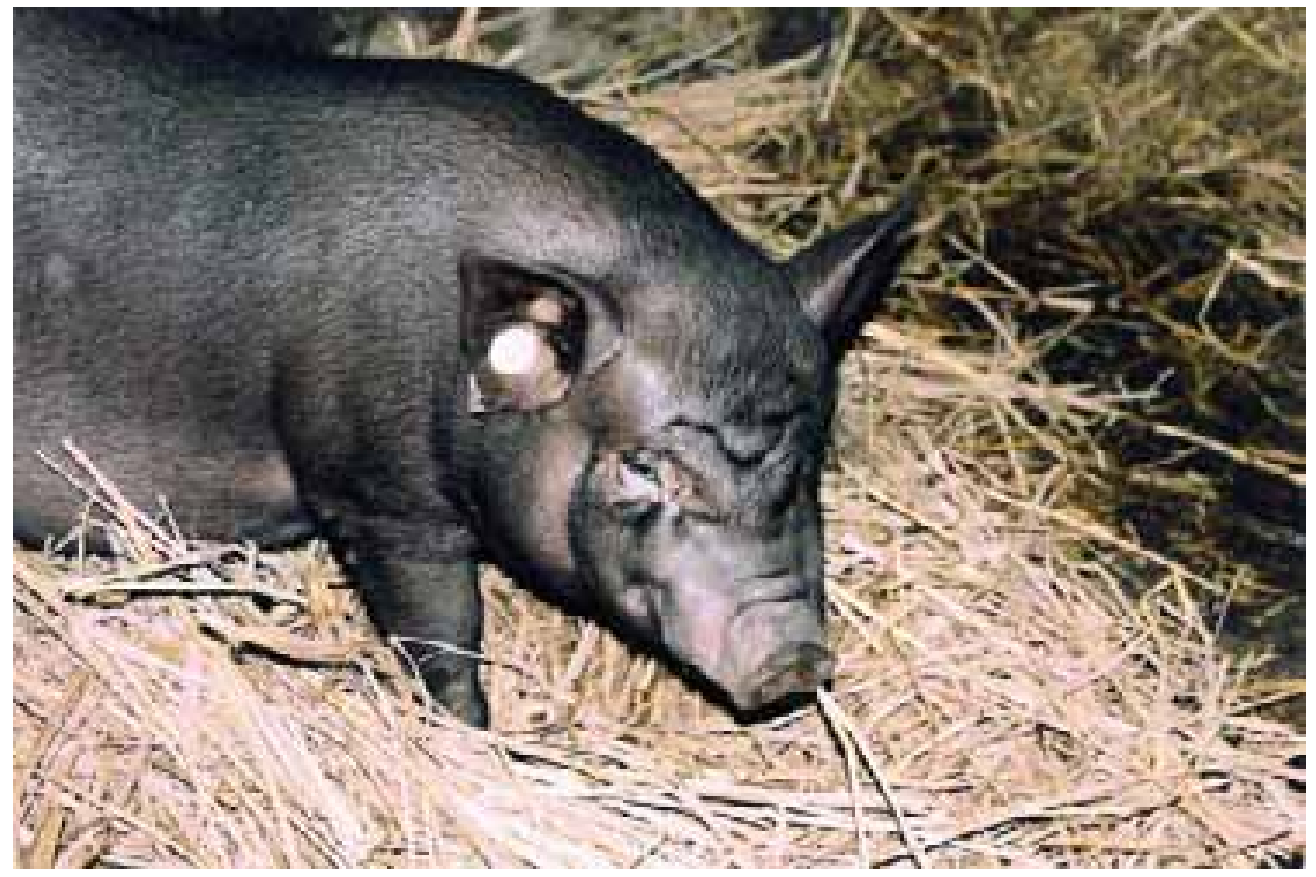

Figure 3. I pig portrait. 
breeds in traditional farming in the 1960s. The I pig was very easy for poor peasant families to keep. Not many diseases occurred in the herds, and no vaccination program had to be applied. Feeding them was easy, their diet consisting of green vegetables, grass and agricultural by-products, indeed sometimes their keepers did not feed them at all during periods of armed conflict. The I pig was a main festive dish on the tables of Vietnamese people during periods of war. Nevertheless, the I pig could not comply with the changed market and consumer requirements for less bacon and more meat in a short time in the post war period - this was the tragedy which befell the breed.

The I pig breed had two types: Black and Goc (Rough). Both were bred in Nam Dinh (Red River Delta, 100 km from Hanoi). The Black type no longer exists. The Goc type is kept in Thanh Hoa district by the project "Livestock Resources Conservation" financed by the Government of Vietnam and around 100 animals remain there.

The I pig has many characteristics that are not evident in intensive breeds. Some of these characteristics are:

- Resistance to diseases, low feed requirements, the ability to search for its own fodder on pasture.

- High fertility and prolificacy but low weight and low performance levels.

- Bacon and meat of excellent smell and taste.

The bacon of the I pig is very tasty and the percentage of fat of the slaughtered I pig is $63 \%$. I pig stock matures early (six months), and it is for this reason that I piglets can be slaughtered and exhibit good eating qualities while piglets of other breeds are only bone and skin at that age.

During the war period, the people had only rice as a main subsistence food source, while the I pig had to forage for grass and vegetables around the house. Later, with the development of Vietnamese agriculture, I pigs could benefit from agricultural by-products other than poor grasses along harvested rice fields, and as a result their growing parameters improved significantly (Table 3).

\section{Characteristics of I pig reproduction}

Their early sexual maturity is the principal advantage of the I pig. The pigs are prolific, tenacious, have few requirements, and tolerate the extreme climatic conditions of humidity and heat. The sexual maturity of I pigs occurs relatively early. Males try to jump at the age of 3-4 weeks and at 40 days of age their semen is fertile, however the best age of first reproduction is at 6 months. Females can show heat and may become pregnant at the age of four to five months; however the optimum period for their first pregnancy is after eight months of age (35-40 kg weight). Their average heat period is 19-21 days and oestrus lasts for four to five days the optimum day for service being the second day. Their gestation period is 110-115 days and litter size averages 8.8-11.3. Females are capable of reproduction until the age of 10-11 years (Viet Ly, 2001c).

\section{Mong Cai pig (in mass production)}

This breed was developed not less than 150 years ago. Thanks to a conducive seaside environment rich in sea products, Mong Cai, with its famous hanging abdomen is a pig lovers' pig breed in Vietnam. The Mong Cai breed originated in Mong Cai district, a small, pleasant district of Quang Ninh province, the most picturesque region of north-east Vietnam on the Chinese frontier bordering the famous Ha Long bay. Mong Cai pig meat is very tasty. A remarkable characteristic of this breed is its beautiful coat with three colours: black, white and pink (Figure 4). They are also very gentle to handle. Mong Cai pig has been common in the north of Vietnam since the 1960s and 1970s and after the war (since 1975) this breed expanded widely into central and even south Vietnam. Due to their superior parameters to those of I pig, expansion of 
Mong Cai breed restricted the production area of the I pig. The Mong Cai pig, once endangered, is now playing an important role in pig production in many households practicing a semi-intensive production system. Nowadays farmers often use Mong Cai females for crossing with males of intensive foreign hybrids as Mong Cai males are considered less valuable for breeding, and this may prove dangerous for the breed in the future (Viet Ly, 2001b).

The two types of Mong Cai pigs are the heavyweight and lightweight. However spontaneous selection threatens the lightweight Mong Cai pig, which is regularly crossed with the heavyweight type. This is the reason why one generally finds the heavyweight Mong Cai in peasant homes.

The heavyweight type has a high shank, long trunk, big tubular bone, separated claw and a long muzzle with a strong build. Their adult weight is generally between $140 \mathrm{~kg}$ and $170 \mathrm{~kg}$ although sometimes up to $200 \mathrm{~kg}$. Their fatty layer is formed late in the $8-9^{\text {th }}$ months of age. Most of them have 14 dugs and some 12 dugs. The average litter size is $10-12$ piglets.

The lightweight type of Mong Cai is of a low and thin build with a short trunk, small tubular bone, close claw and short muzzle. Its maximum weight is $85 \mathrm{~kg}$. Its fatty layer is formed in around the $6^{\text {th }}$ month of age. Most of them have 12 dugs and some 14 dugs. The average litter size is 8-9 piglets.

For reproductive parameters of the Mong Cai pig, also see table 4 .

\section{Cattle breeds}

\section{URIU cattle endangered}

Uriu cattle belong to the Bovina family. The breed was naturally selected throughout the centuries for adaptation to the micro-ecology of the region of Nam Dan-Nghe An

(Figure 5.) Table 5 shows the standard characteristics of the breed (Viet Ly, 2001a).

Table 3. I pig weight, in kilograms, at the age of 1 to 4 years 1963and 1994 (Viet Ly, 2001c).

\begin{tabular}{lcc}
\hline Age (years) & In 1963 & In 1994 \\
\hline 1 & 38.4 & 49.4 \\
2 & 44.4 & 58.5 \\
3 & 48.4 & 67.7 \\
4 & 49.4 & 73.4 \\
\hline
\end{tabular}

Table 4. Reproductive parameters of Mong Cai pig (Viet Ly, 2001b).

\begin{tabular}{llc}
\hline Parameters & \multicolumn{1}{c}{ Unit } & Average \\
\hline Sexual activation cycle & Day & 21 \\
Heat period & Day & $3-4$ \\
Sexual maturity & Month & $6-8$ \\
Pregnancy period & Day & $110-120$ \\
Number of litters in the year & Litter & $1.5-2$ \\
Number of piglets in a litter & Piglet & $10-14$ \\
Piglet weight after farrow & Kg & $0.45-0.5$ \\
Piglet weight after delactation & Kg & $6-7$ \\
Period between two farrows & Month & $5.5-6$ \\
\hline
\end{tabular}




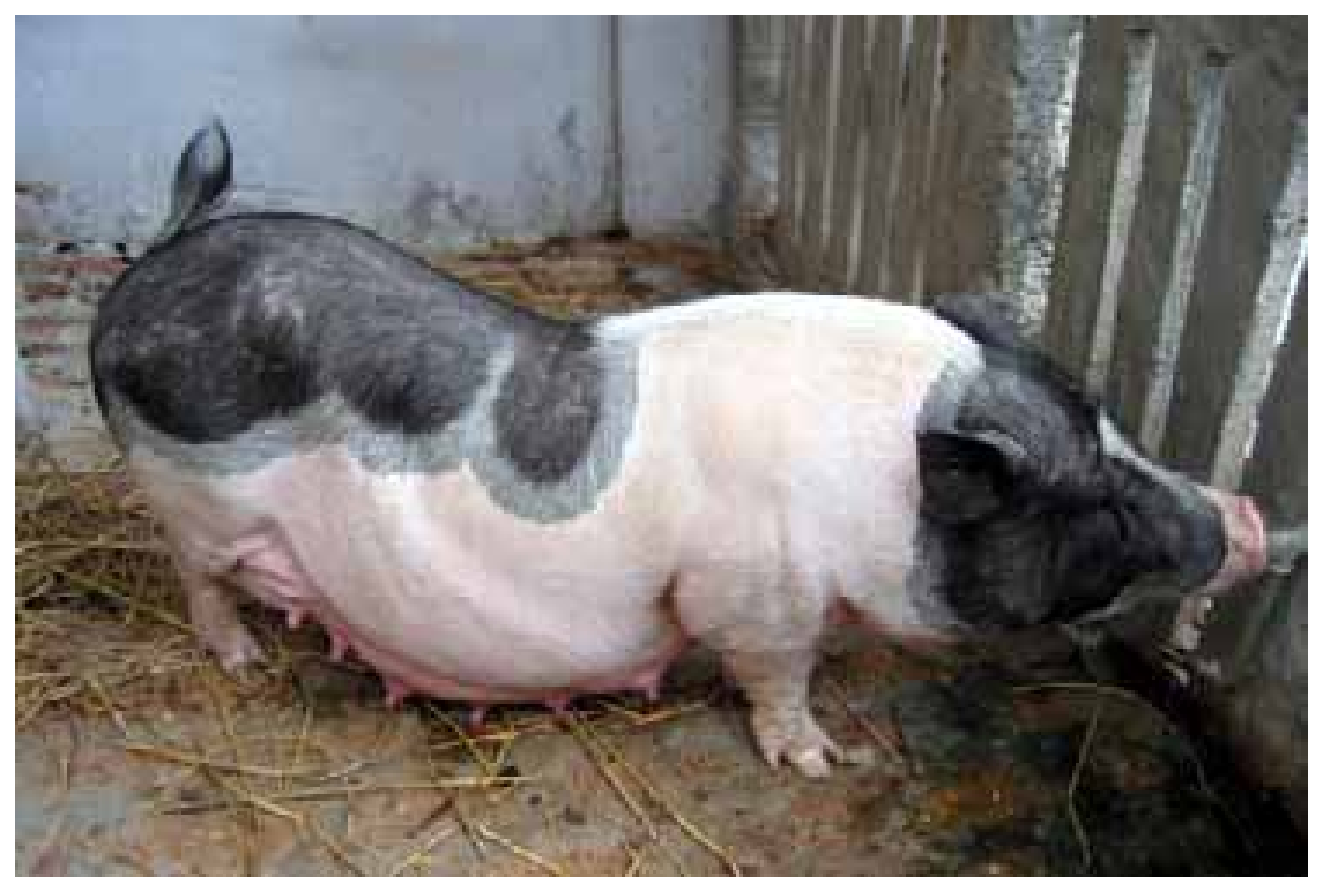

Figure 4. Mong Cai pig female.

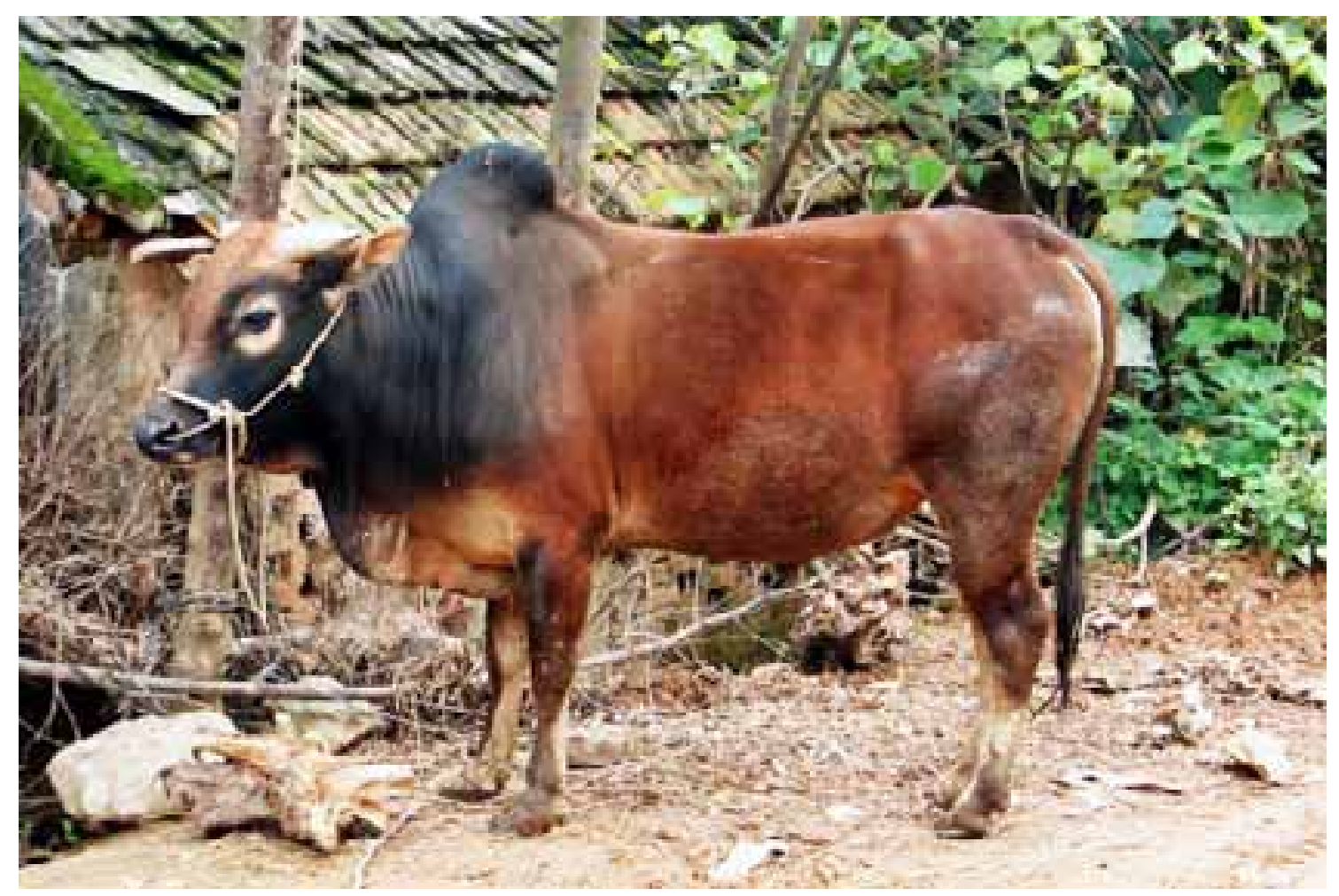

Figure 5. Uriu bull. 
Table 5. Some standard characteristics of adult Uriu cattle (Viet Ly, 2001a).

\begin{tabular}{cccccc}
\hline $\begin{array}{c}\text { Withers } \\
\text { height }(\mathrm{cm})\end{array}$ & $\begin{array}{c}\text { Chest } \\
\text { contour }(\mathrm{cm})\end{array}$ & $\begin{array}{c}\text { Chest } \\
\text { depth }(\mathrm{cm})\end{array}$ & $\begin{array}{c}\text { Chest } \\
\text { width } \\
(\mathrm{cm})\end{array}$ & $\begin{array}{c}\text { Weight }(\mathrm{kg}) \\
\text { female/male }\end{array}$ & $\begin{array}{c}\text { Trunk } \\
\text { cross-length }(\mathrm{cm})\end{array}$ \\
\hline 1134 & 157 & 56 & 34 & $210 / 324$ & 122.1 \\
\hline
\end{tabular}

Table 6. Reproductive parameters of Uriu cattle (Viet Ly, 2001a).

\begin{tabular}{lcc}
\hline Parameters & Unit & Average \\
\hline Age of the first sexual maturity & Months & $18-20$ \\
Age of the first pregnancy & Months & $22-24$ \\
Age of the first calving & Months & $33-34$ \\
Period between two farrows & Months & $14-32$ \\
\hline
\end{tabular}

Uriu cattle remaining in the Nghe An and Ha Tinh region number only in the tens of thousands. The shortage of water for plants especially during the dry season in the central coast of South Land causes serious problems in feed resources in Nghe An region which is endowed with poor soil and perhaps the worst climate in Vietnam. The area frequently suffers from floods and devastating typhoons (the locals say, "the typhoon was born here and comes back often to visit"). Summers are very hot and dry, while winters are cold and rainy.

Temperatures vary from $6^{\circ} \mathrm{C}$ to $42^{\circ} \mathrm{C}$ and the humidity between $31 \%$ and $86 \%$, while the average rainfall is from $1900 \mathrm{~mm} /$ year to $3009 \mathrm{~mm} /$ year. Table 6 shows the parameters of the breed. Traditionally Uriu cattle are raised by peasant smallholders for multipurpose use in agricultural production. Despite the Vietnamese economic growth in the last ten years, it has always been impossible to introduce vehicles or any machinery into Nghe An region, especially to Nam Dan village because its soil is gravely, infertile and full of rocks. Uriu are kept mostly for working in the fields, for transporting goods to the village, and at the end of their life for supplying meat for their keeper. Well adapted to the conditions, the Uriu is closely associated with paddy rice cultivation (Figure 6) and plays an important role in the whole agriculture of Nam Dan. Uriu cattle are also considered as members of the farmer's family not only for working their field and fertilizing their land, but also for transportation in rural areas.

The colour of the Uriu varies from yellow to brown. The male has a sickle form of a hump with which it can apply great pulling power to the yoke (U means yoke, and Riu means sickle). The female is used both for reproduction and meat production. The milk production of the female is just enough for feeding calves (Figure 7).

\section{Chicken breeds}

\section{Dong Tao chicken (increasing)}

The Dong Tao chicken has been saved by the demands of exigent consumers. Living in increasingly good economic conditions, some Vietnamese people are returning to their old traditions looking for different exotic dishes. The Dong Tao chicken is an indigenous breed, originated from Hai Hung Province (Hung Yen - Red River Delta). They are red with variants $(90 \%)$ or yellow $(10 \%)$ coloured plumage with no special pattern on the feathers (4). They have yellow skin, shanks and feet. The comb may be of pea $(90 \%)$ or single $(10 \%)$ type and eggshells are 


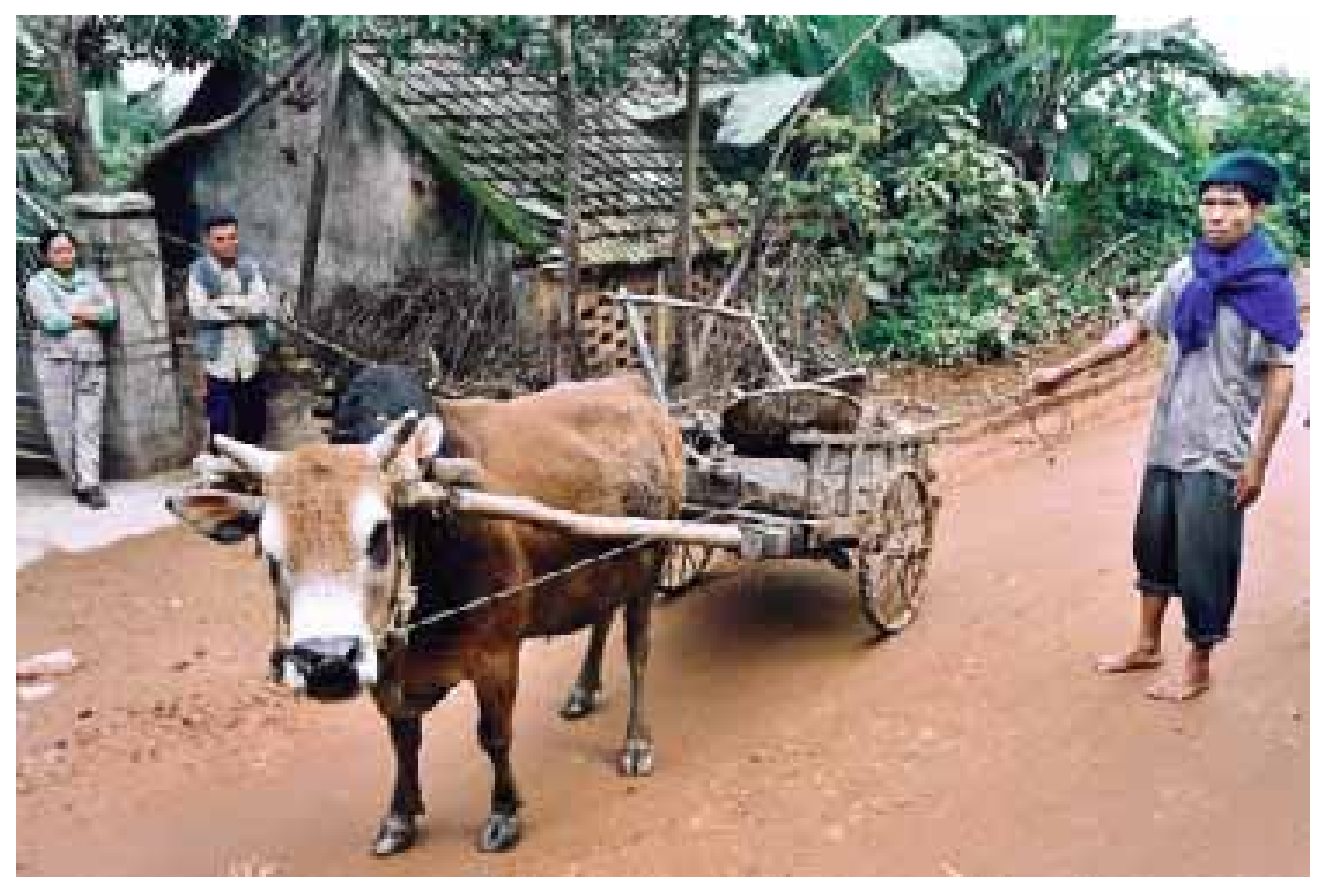

Figure 6. Uriu bull in every day work as a drawing power.

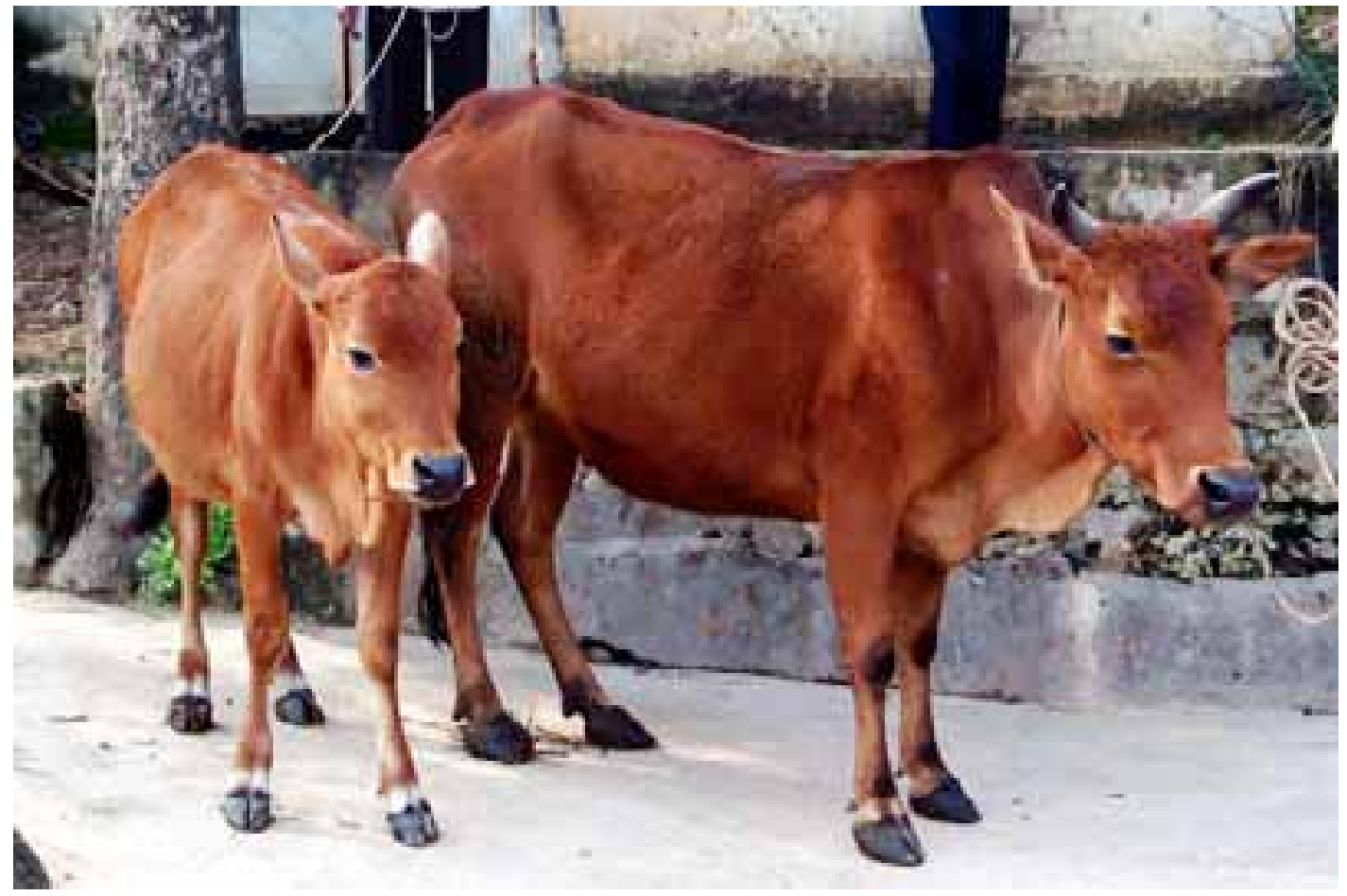

Figure 7. Uriu cow and calf. 


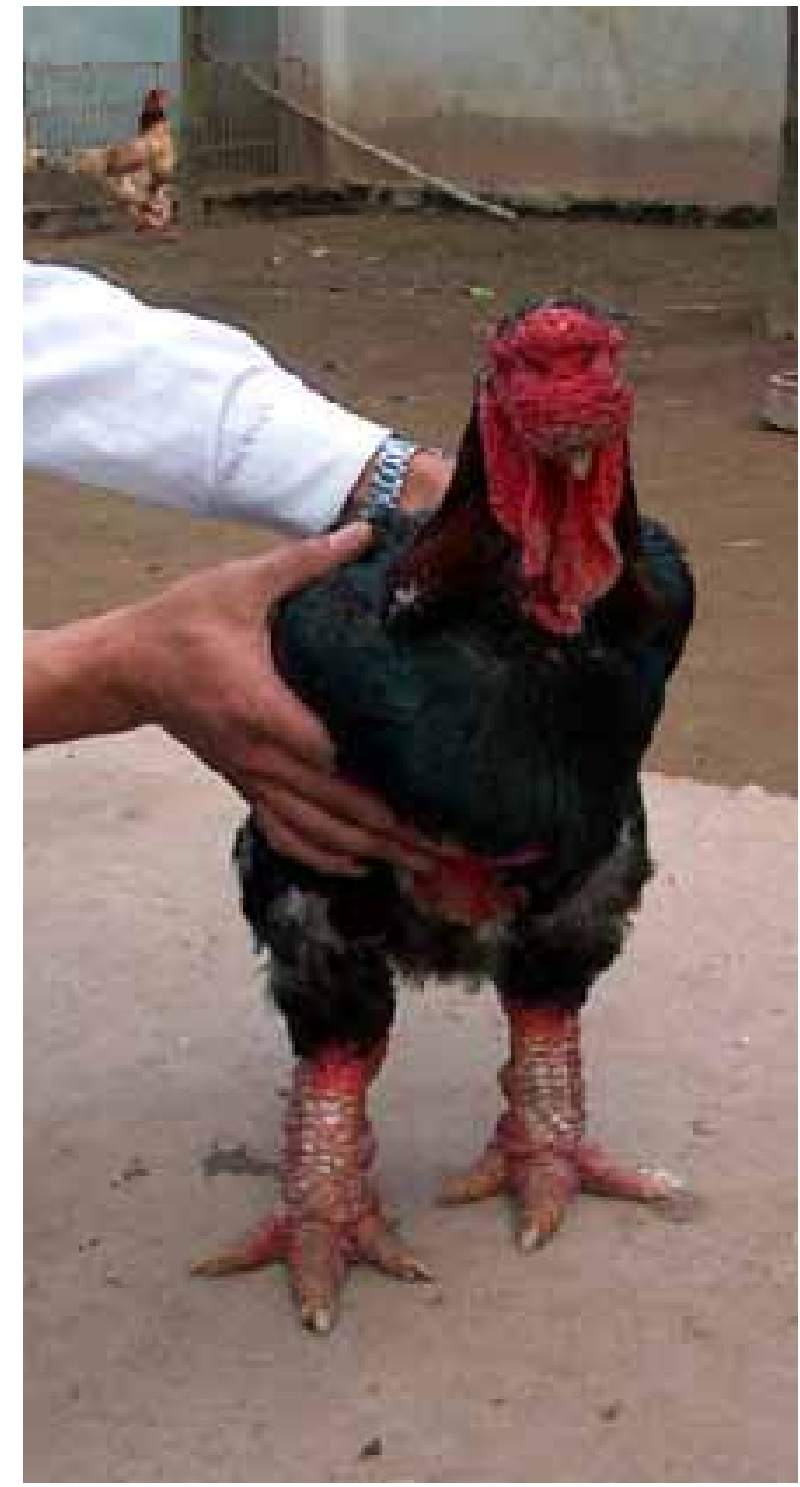

Figure 8. Dong Tao chicken (male).

brown in colour. They have very big shanks and a large skeleton (Figures 8 and 9). Adult males weigh on average $3.6 \mathrm{~kg}$, and females $2.6 \mathrm{~kg}$. Dong Tao chicken are very popular in the district of Dong Tao villages. The breed shows rapid growth, and produces tasty eggs and meat.

The reproductive parameters of Dong Tao chicken were estimated in a trial (Nga et al., 1999) as follows:
- In a 36-week egg production period, average egg production was 68 eggs per hen with a feed consumption of $4.1 \mathrm{~kg}$ per 10 eggs.

- The average weight of eggs was $45.3 \mathrm{~g}$ at the chicken's age of 38 weeks. Egg fertility was estimated as $89 \%$.

- Hatchability was $70.1 \%$ compared to the total hatching eggs.

- The Dong Tao chicken is famous for its very big shank.

The most valuable dishes in the Vietnamese and Chinese kitchen are duck tongue and chicken shank. With its particularly big shank Dong Tao chicken meets the gourmet tastes of Vietnamese people. The breed might have been selected centuries ago especially for the size of its shank, to raise the yield of that table delicacy. Due to the conservation program supervised by the National Institute of Animal Husbandry, Dong Tao chicken spreading in many households around Hai Duong. It is hoped that by virtue of its famous taste Dong Tao chicken will be saved.

\section{Duck breeds}

\section{Bau Qui duck (decreasing)}

Many years ago, Vietnam created two distinct duck types, one for egg and one for meat production. The Bau Qui duck is considered a meat duck in traditional farming (Figure 10.). Their origin is Quy Chau village in the highlands of Nghe An region, $150 \mathrm{~km}$ from Vinh, the central town of Nghe An. Quy Chau and its surrounds are isolated from civilisation. Inhabited by the Thai ethnic group, small villages are girt by wonderful mountains and streams (Figure 11). A long-standing tradition of Quy Chau's Thai ethnic group is to kill all animals different from their indigenous breeds, those coming from other parts of the mountains. People believe that foreign animals bring in bad luck for their own flocks. Due to this 


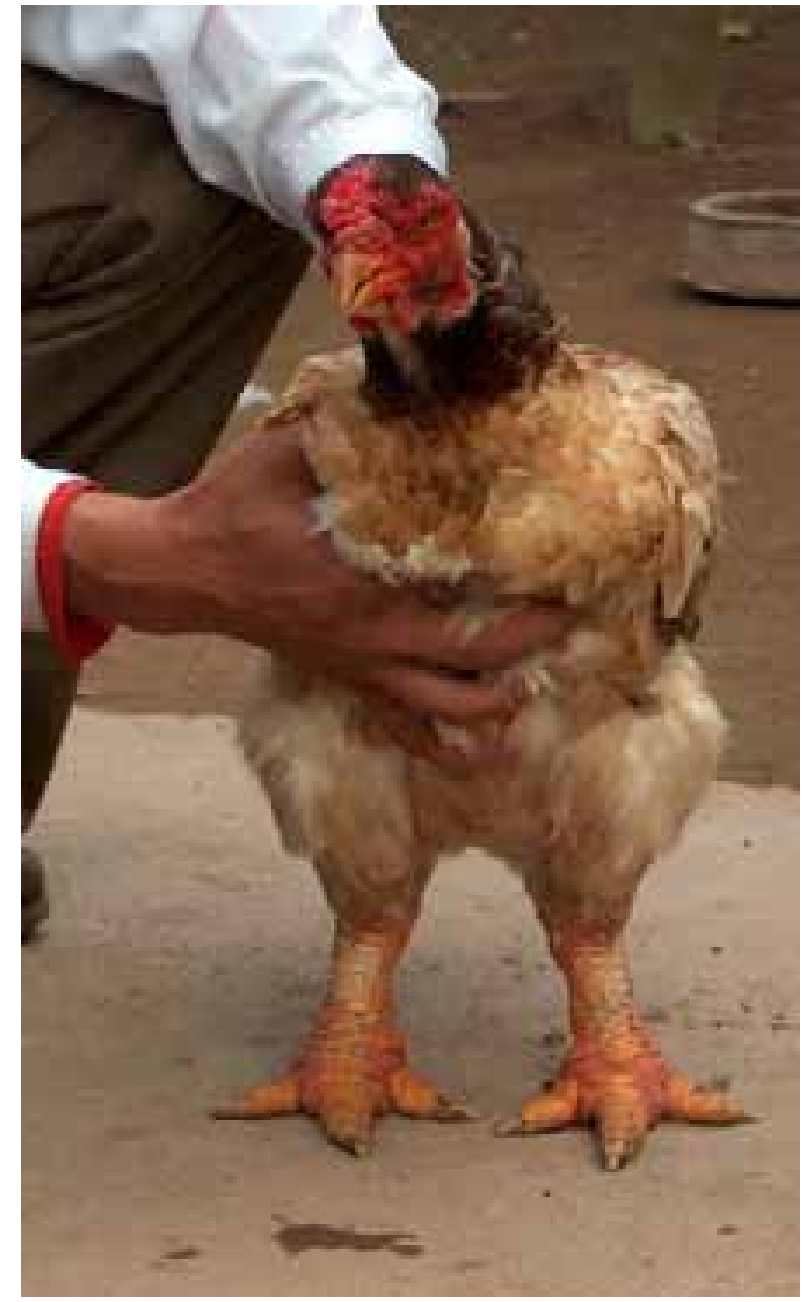

Figure 9. Dong Tao chicken (female).
Thai tradition, purebred Bau Qui duck can still be found in that region (Table 7).

Bau Qui ducks are very clever at finding their natural feed which consists mainly of fish and insects, and which they can obtain from paddy fields, streams or forests.

Sometimes they get rice, corn and by-products from kitchens and fields. They are highly adapted to the hot environment and have high survival ability. Their meat is delicious and valuable due to the high essential amino acid content (Chuyen et al., 2001). Like any other local poultry the breed is threatened, as they can easily disappear due to their low production levels and crossing with other intensive ducks, which were introduced into this region in the 1990s.

\section{Governmental activities to conserve animal genetic resources}

To protect animal genetic resources, the Vietnamese government is supporting different genetic conservation activities. The National Institute of Animal Husbandry (NIAH) is the leading institute managing the conservation activities of AnGR. The institute consists of ten research departments and a series of research centres, with different

Table 7. Reproductive parameters of Bau qui duck (Chuyen et al., 2001).

\begin{tabular}{lcc}
\hline Parameters & Unit & Average \\
\hline Age of the first egg-laying & Days & $190-210$ \\
Weight at the first egg-laying & $\mathrm{kg}$ & $1.6-1.9$ \\
Age of the first mating of the male & Days & $180-200$ \\
Weight of male at the first mating & $\mathrm{kg}$ & $1.8-2.0$ \\
Egg laying period per year & Days & 132 \\
Eggs number per year & Eggs & 80,8 \\
Eggs fertility & $\%$ & $97.2-98.19$ \\
Hatchability by brooding & $\%$ & $90.9-92.7$ \\
Hatchability by artificial incubation & $\%$ & $93.5-94.5$ \\
Mortality at the age of 25th day & $\%$ & 4.6 \\
Mortality at the age of 70th day & $\%$ & 4.8 \\
Body weight at the $60^{\text {th }}$ day age (free range and self-feeding) & $\mathrm{g}$ & 1055 \\
Body weight at the $120^{\text {th }}$ day age (free range and self-feeding) & $\mathrm{g}$ & 1920 \\
\hline
\end{tabular}




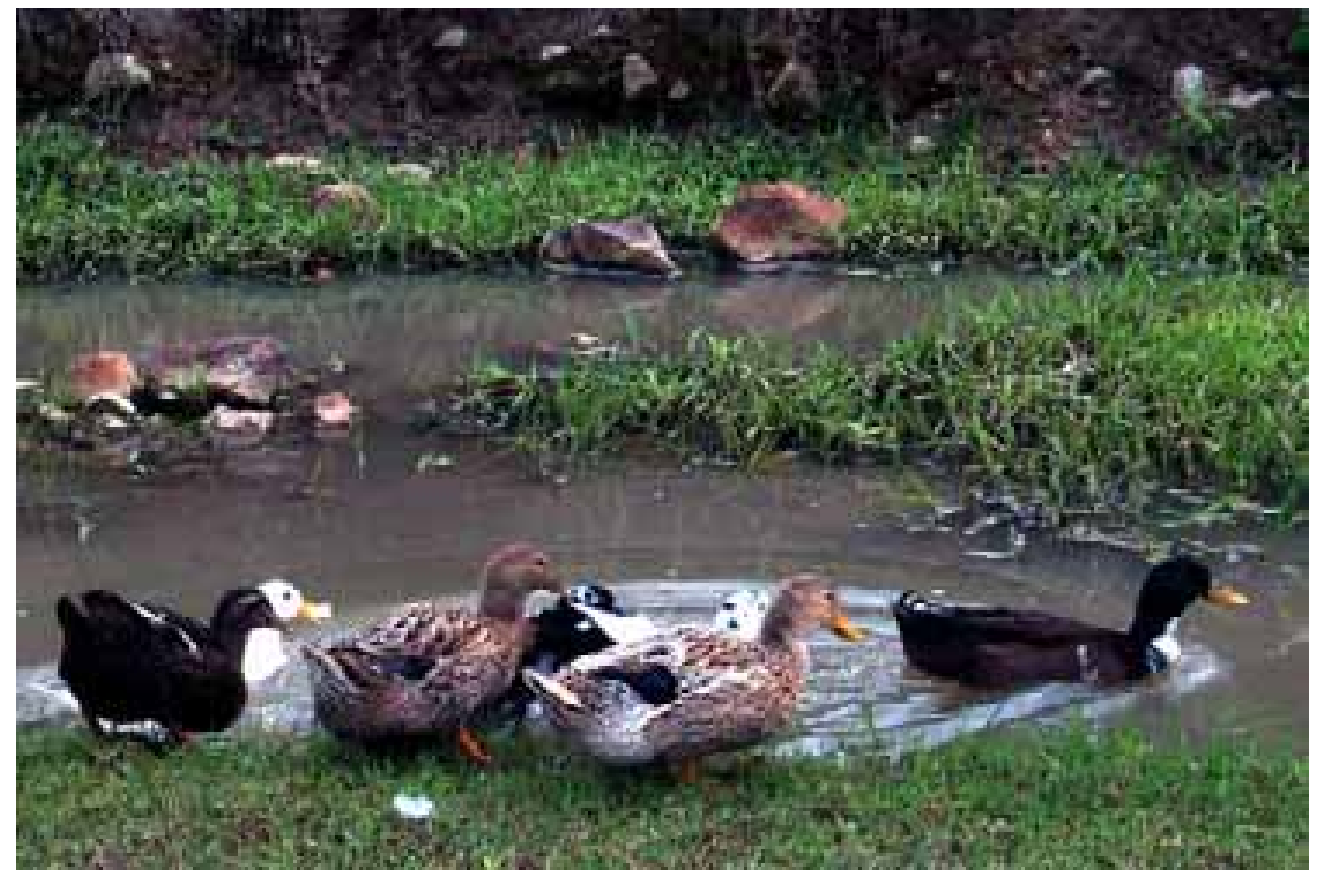

Figure 10. Bau Qui ducks.

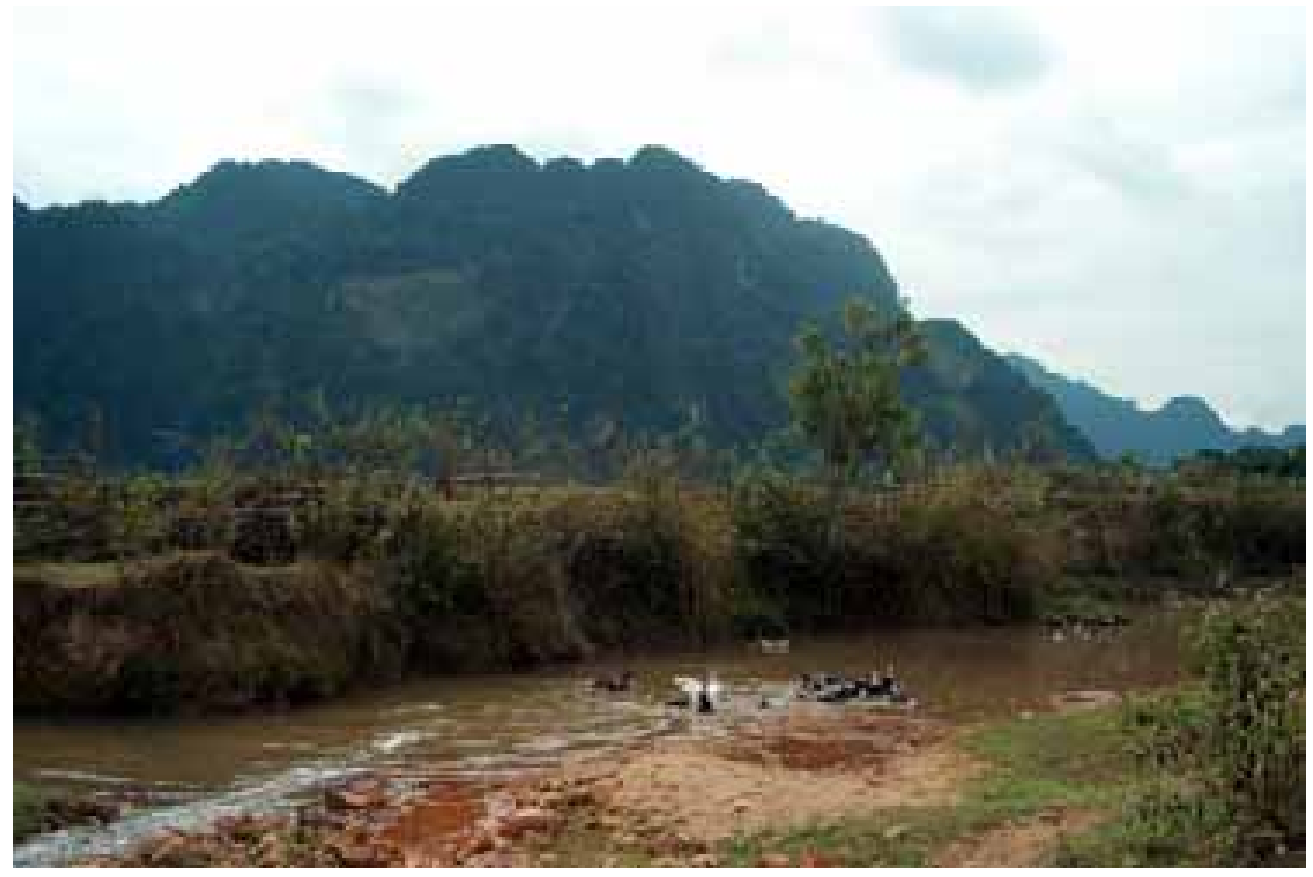

Figure 11. Bau Qui habitats.

breeding and research objectives in pig, cattle, buffalo, horse, goat, rabbit, chicken, duck and even deer and ostrich production. Concerning AnGR in Vietnam, NIAH is responsible for:
- Distributing animals throughout their original habitats, providing financial and technical support for organizations and households managing the animal husbandry. 
- Keeping animals at universities and research institutions for the purpose of examining their physiology and reproduction parameters.

- Increasing the size of breeds having market potential.

- Cooperating with other projects inside and outside Vietnam to establish step by step conservation systems for genetic materials.

- Establishing biodiversity information systems and publishing documents (Viet Ly et al., 2000, Thien, 1998).

Besides the breeding and research activities of NIAH, there are several governmental institutions involved in the management of AnGR. The National Institute of Veterinary Medicine is responsible for animal health studies in the country. Universities are taking part in animal research through their faculties such as the Animal Production and Veterinary Faculties of Hanoi Agricultural University, the University of Agriculture and Forestry at Hue, Nong Lam University at Thu Duc near Ho Chi Minh City, Can Tho University, the University of Agriculture and Forestry at Thai Nguyen, the universities at Thanh Hoa and Vinh and others. These universities belong to the Ministry of Education and Training. At ministry level there is a Committee of Science on Animal Research, which is responsible for regulating and formulating research projects in the country and also evaluating experimental results. Every year, some appropriate technological advances are identified and transferred to production through a network of support services.

\section{List of References}

Dong Xuan, D.T. \& I. Szalay. 2003.

Possibilities and aspects to introduce foreign poultry genetic resources to Central Vietnam. Proc. $3^{\text {rd }}$ Vietnamese-Hungarian Conference "Domestic animal production and aquaculture-Quality and rural development" pp. 47-54.
Chuyen., D., L. Viet Ly, N.D. Nhu, L. Minh Sat, N.V. Thu, L. Xuan Dong, C. Xuan Tuan, V.V. Van, L. Hai Ly, L.T. Minh \& D.T. Dung. 2001. Dac diem sinh hoc va kha nang san xuat giong vit Bau Quy tinh Nghe An (Physiological and production parameters of the Bau Quy breed of Nghe An). Vietnam livestock Genetic Resources Conservation. Scientific papers on Animal production-National Institute of Animal Husbandry- Tu Liem-Hanoi; www.vcn.vnn.vn/qg.

Tieu, H.V., L. Viet Ly, V.V. Su \& L. Minh Sat. 2001. A 2001 summary on Vietnam livestock Genetic Resources Conservation. Project "Vietnam Livestock Genetic Ressources Conservation"; www.vcn.vnn.vn/qg/tienganh.

Le Ly, H. 1994. Vietnam. Elsworth Books, Hong Kong, pp. 208.

Nga, L.T., N. Dang Vang, T. Cong Xuan, P. Duc Tien \& N. Manh Hung. 1999. The productivity of Dong Tao chicken and hybrids between Dong Tao and Tam Hoang. Scientific papers on Animal productionNational Institute of Animal Husbandry.- Tu Liem-Hanoi; www.vcn.vnn.vn/qg/tienganh.

Viet Ly, L. 1998. A review on animal production and animal research in Vietnam. Proceeding of "The first VietnameseHungarian Workshop on Small Animal Production for the Development of Sustainable Integrated Farming Systems. Proceedings". Thu Duc-Ho Chi Minh City, Vietnam, pp 18-25.

Viet Ly, L. 2001a. Bao ton quy gen Bo U Dau Riu. (Uriu cattle gene conservation). Vietnam livestock Genetic Resources Conservation. Scientific papers on Animal 
production- National Institute of Animal Husbandry.- Tu Liem-Hanoi; www.vcn.vnn.vn/qg.

Viet Ly, L. 2001b. Bao ton quy gen lon Mong Cai. (Mong Cai pig gene conservation). Vietnam livestock Genetic Resources Conservation. Scientific papers on Animal production- National Institute of Animal Husbandry.- Tu Liem-Hanoi; www.vcn.vnn.vn/qg.

Viet Ly, L. 2001c. Bao ton quy gen lon I ("I" pig gene conservation). In Animal Genetic Resources in Vietnam. National Institute of Animal Husbandry; www.vcn.vnn.vn/qg.
Viet Ly, L., L. Minh Sat, \& V.V. Su. 2000. Project "Vietnam livestock genetic resources conservation (VLGRC)" Background, methodology, activities, achievement, programs. Vietnam livestock Genetic Resources Conservation. Scientific papers on Animal production, National Institute of Animal Husbandry. Tu Liem-Hanoi; www.vcn.vnn.vn/qg/tienganh.

Thien, N.V. 1998. Conservation and use of animal genetic resources in Asia Pacific. Proceeding of Third Regional Training Workshop on the Conservation of Domestic Animal Diversity and the Fourth National Coordinators Meeting - FAOBangkok. March 1998. GCP/RAS/144/JPN Document 4. 